\title{
Reponses of sheep to a vaccination of entodinial or mixed rumen protozoal antigens to reduce rumen protozoal numbers
}

\author{
Yvette J. Williams, Suzanne M. Rea, Sam Popovski, Carolyn L. Pimm, Andrew J. Williams, Andrew \\ F. Toovey, Lucy C. Skillman and André-Denis G. Wright*† \\ CSIRO Livestock Industries, Centre for Environment and Life Sciences, Private Bag 5, Wembley, WA, 6913, Australia \\ (Received 8 November 2006 - Revised 8 June 2007 - Accepted 19 June 2007)
}

Two rumen protozoa vaccine formulations containing either whole fixed Entodinium or mixed rumen protozoa cells were tested on Merino sheep with the aim of decreasing the number and/or activity of protozoa in the rumen. Negative control (no antigen) and positive control (Tetrahymena corlissi antigens) treatments were also included in the experiment. Blood and saliva were sampled to measure the specific immune response. Protozoal numbers in the rumen were monitored by microscopic counts. Vaccination with protozoal formulations resulted in the presence of specific IgG in plasma and saliva, but saliva titres were low. Titres after secondary vaccination were higher $(P<0 \cdot 05)$ than after primary vaccination. There was a moderate $\left(r^{2} 0.556\right)$ relationship $(P<0.05)$ between plasma and saliva titres for the rumen protozoal vaccine formulations. Rumen protozoa were not decreased $(P>0.05)$ by the vaccination and there was also no difference $(P>0.05)$ between treatments in rumen fluid ammonia-N concentration or wool growth. In vitro studies investigated the binding ability of the antibodies and estimated the amount of antibody required to reduce cell numbers in the rumen. The studies showed that the antibodies did bind to and reduced protozoa numbers, but the amount of antibody generated by vaccination was not enough to produce results in an in vivo system. It is suggested that the vaccine could be improved if specific protozoal antigens are determined and isolated and that improved understanding of the actions of protozoa antibodies in rumen fluid and the relationships between levels of antibodies and numbers of protozoa in the rumen is needed.

Antigens: Antibodies: Rumen protozoa: Sheep

The rumen is populated with many types of micro-organisms, which degrade and ferment the feed eaten by the animal. However, from a production point of view, not all the micro-organisms present in the rumen are essential or provide efficient conversion of feed to protein ${ }^{1}$. Many studies have shown that if protozoa are removed from the rumen, a process known as defaunation, wool growth can be increased due to increased microbial protein outflow to the small intestine ${ }^{1-3}$. However, successful defaunation methods can be laborious and impractical in normal animal husbandry settings and chemical-based methods can be detrimental to animal health ${ }^{3,4}$. Also, unless defaunated animals remain segregated from faunated animals, or are regularly re-treated with defaunation chemical, the ciliated protozoa are able to re-establish themselves in the rumen. An immunological approach to manipulating rumen microbial populations, specifically rumen ciliates, was investigated by Gnansampanthan ${ }^{5}$. Serum antibodies raised to rumen ciliates were shown to have an immobilizing effect on a mixed rumen ciliate population in vitro, which decreased the ciliates' predatory activity on bacteria ${ }^{6}$. Until now there has been no in vivo examination of the effects that protozoal vaccines have on the numbers of ciliate protozoa in the rumen. The aim of the present experiment was to examine changes in rumen protozoal numbers in Merino sheep that were vaccinated with two protozoal formulations. The hypothesis was that immunization of sheep with a vaccine containing whole fixed Entodinium or mixed rumen protozoal cells as antigens would decrease protozoa numbers in the rumen and that this change in numbers would be indicated by a decrease in rumen ammonia-N concentration and increased wool growth.

\section{Experimental methods}

\section{Experimental design, animals and management}

The experiment was conducted in 2004 using eighty Merino weaners. There were four treatments in a randomized complete block design with twenty sheep in each treatment group. The experimental unit was an individual sheep.

The treatments were:

Negative control - PBS and adjuvant.

Positive control - Tetrahymena corlissi + PBS and adjuvant.

Entodinium spp. + PBS and adjuvant.

Mixed rumen protozoa (Entodinium, Isotricha, Dasytricha, Polyplastron) + PBS and adjuvant.

Abbreviations: LW, live weight; PBST, PBS and 0.05\% Tween 20 solution; RFU, relative fluorescence unit.

$\dagger$ Present address: CSIRO Livestock Industries, Queensland Bioscience Precinct, 306 Carmody Rd, St Lucia, Queensland, 4067, Australia

*Corresponding author: André-Denis Wright, fax +61 73214 2900, email andre-denis.wright@csiro.au 
The free-living ciliated protozoan, T. corlissi, was used for positive control because it was easily cultured and dense cultures could be grown quickly in large volumes of media. Previous experiments at this laboratory have shown that site reactions and serum immune responses are generated when sheep are vaccinated with $T$. corlissi. The preparations of $T$. corlissi contained a single species, as they were pure cultures obtained from the American Type Culture Collection.

Protozoa from the Entodinium genus were used as a treatment as they are the most common and predominant genus in almost all ruminants ${ }^{1}$.

The present experiment was approved by the CSIRO Animal Ethics Committee (WA group) and conducted in accordance with the Australian code of practice for the care and use of animals for scientific purposes ${ }^{7}$.

Merino wether weaners (1 year old) with a live weight (LW) of 34.1 (SE 0.35$) \mathrm{kg}$ were housed in individual pens at the CSIRO animal house facility in Perth in late March 2004 and allowed 6 weeks to acclimatize to their new surroundings and diet. Sheep were then shorn, weighed and allocated to the treatment groups by stratified randomization ${ }^{8}$ using LW (34.4 (SD 0.24) kg) and fleece weight $(2.30$ (SD 0.029$) \mathrm{kg}$ ). A 4-week pre-treatment covariate period then followed, in which wool growth was measured and sheep were sampled for blood, saliva and rumen fluid to determine pre-vaccination antibody titre levels, plasma urea-N concentrations and numbers of rumen protozoa. The experimental treatment period began with primary vaccination (day 0) and ran for 18 weeks. Secondary vaccination occurred on day 42 and production measurements occurred between days 84 and 126 .

Animals were drenched with antihelmintics in accordance with the manufacturers instructions on days 18 (Scanda ${ }^{\circledR}$ (Schering-Plough Coopers Animal Health Ltd, New Zealand) - active ingredients: Levamisol and Oxfendazole) and 48 (Triton ${ }^{\circledR}$ (Merial, Australia) - active ingredients: Ivermectin, Levamisol and Albendazole) to remove intestinal worms.

An outbreak of scabby mouth (contagious ecthyma) occurred around day 5 and gradually worked through $60 \%$ of the sheep for the rest of the experiment. No animal suffered from reduced feed intake because of infection and vaccination treatment had no influence $(P<0.05)$ on the number of animals contracting the disease or on the length of time symptoms were present on the animal.

Sheep were offered pelletized oaten hay-based rations as a single feed each morning and they had continual access to water. The pellets comprised chopped oaten hay $(630-700 \mathrm{~g} / \mathrm{kg})$, cereal grains $(140-200 \mathrm{~g} / \mathrm{kg})$, lupins $(100-120 \mathrm{~g} / \mathrm{kg})$, Siromin ${ }^{9}$ mineral mix $(20 \mathrm{~g} / \mathrm{kg})$ and a binder ingredient $(20-50 \mathrm{~g} / \mathrm{kg})$. On a DM basis they contained around $930 \mathrm{~g} / \mathrm{kg}$ organic matter, $90 \mathrm{~g} / \mathrm{kg}$ crude protein and $420 \mathrm{~g} / \mathrm{kg}$ neutral detergent fibre. The ration was intentionally formulated to be excessive in metabolizable energy requirements relative to metabolizable protein requirements ${ }^{10}$ so that any increase in protein flowing from the rumen due to the experimental treatments would be used efficiently, increasing the chances of observing changes in animal production parameters, in particular wool growth. The ration was offered at a rate that was $20 \%$ greater than what was calculated to meet estimated metabolizable energy requirements for $60 \mathrm{~g} \mathrm{LW}$ gain/d and $6 \mathrm{~g}$ clean wool growth $/ \mathrm{d}^{10}$. This worked out to be around
$23 \mathrm{~g} \mathrm{DM} / \mathrm{kg} \mathrm{LW}$. The amount of ration offered was adjusted every 6 weeks to accommodate the growth of the animals.

Samples of feed offered were collected twice weekly, dried at $60^{\circ} \mathrm{C}$ and ground through a $1 \mathrm{~mm}$ screen for chemical analyses. Concentration of organic matter was determined by ashing in a muffle furnace, total $\mathrm{N}$ was determined by combustion in a LECO 2000 N/C analyser (LECO Corporation, St Joseph, MI, USA). Concentration of neutral detergent fibre was determined using the ANKOM method ${ }^{11}$ with the following modifications: samples were digested for $60 \mathrm{~min}$ instead of $75 \mathrm{~min}$ and the acetone rinse step was omitted.

\section{Sources of antigens, preparation of vaccines and immunizations}

Tetrahymena corlissi (American Type Culture Collection $50086)$ stock solutions $(10 \mathrm{ml})$ were established at room temperature and renewed weekly in a modified proteose-peptoneyeast extract medium ${ }^{12}$ - tryptone (pancreatic digest of casein) was used instead of proteose peptone and anhydrate dextrose was added at $0.2 \%$ rather than $0.125 \%$. A fresh stock solution was used to inoculate $250 \mathrm{ml}$ proteose-peptone-yeast extract medium in a $500 \mathrm{ml}$ Schott bottle and was grown for $2 \mathrm{~d}$ at room temperature. The culture was then used to inoculate 2.5 litres proteose-peptone-yeast extract medium in a 5 litre Schott bottle and grown to a concentration of $10^{4}$ cells $/ \mathrm{ml}$ before being killed with $4 \%$ formalin $(\mathrm{v} / \mathrm{v})$. The killed cells were left to settle at room temperature for $3 \mathrm{~h}$, the supernatant was poured off and the remaining slurry (approximately $500 \mathrm{ml}$ ) transferred to a 1 litre Schott bottle. An equal volume of PBS was added, mixed and the cells left to settle again. The cells were then washed with PBS three times and the final cell concentrate was counted and stored at $4^{\circ} \mathrm{C}$.

Rumen protozoa cells were extracted from rumen fluid of two fistulated sheep fed a diet of oaten hay $(900 \mathrm{~g} / \mathrm{kg})$, lupins $(80 \mathrm{~g} / \mathrm{kg})$ and Siromin ${ }^{9}$ mineral mix $(20 \mathrm{~g} / \mathrm{kg})$ based on the methods of Williams \& Coleman ${ }^{1}$. Around $500 \mathrm{ml}$ rumen contents were collected from each animal at a time by suction via a vacuum pump. Rumen contents collections occurred over many days to obtain enough protozoa for use in the vaccines. Each animal only had rumen contents extracted two to three times per week and not on consecutive days. Once collected, the rumen contents were pooled and quickly taken to the laboratory and strained through a layer of cheesecloth. The retained particulate matter was mixed with approximately 2.5 litres warmed $\left(39^{\circ} \mathrm{C}\right)$ acetate-phosphate-bicarbonate buffer ${ }^{13}$, to the consistency of the original rumen contents and again strained through cheesecloth. The strained rumen fluid and washing was combined and then transferred to a 5 litre separatory funnel, where it stood at $39^{\circ} \mathrm{C}$ until the flocculent debris rose to the surface (approximately 30 to $60 \mathrm{~min}$ ). Half to two-thirds of the liquor fraction was siphoned off and the remaining rumen fluid was mixed and allowed to re-separate. The liquor fraction was again siphoned off and formalin was added to the siphoned liquor fraction to a final concentration of $1 \%(\mathrm{v} / \mathrm{v})$. The liquor fraction was then allowed to stand at room temperature for $24 \mathrm{~h}$, during which time the protozoa settled to the bottom. The supernatant fluid was carefully poured off, leaving the protozoa sediment. 
To separate the different sized rumen protozoa, the protozoa sediment was washed with PBS solution on a descending series of Nitex mesh $(300,250,100,80,45,30,20$ and $10 \mu \mathrm{m})$. The material on each filter mesh was kept separate and fixed in $1 \%$ isotonic formalin. The numbers and types of protozoa present in each fraction were then determined using light microscopy. Entodinium species were mostly in the 10 to $20 \mu \mathrm{m}$ fraction and this fraction was used as the stock solution for the Entodinium vaccine. Microscopic observation suggested that this fraction only contained small Entodinium and was not contaminated by other protozoa. The mixed protozoa stock solution was created by mixing several of the different fractions in varying proportions, so that the composition of protozoa was $68 \%$ Entodinium spp., $21 \%$ Dasytricha ruminantium, $7 \%$ Isotricha spp. and 4\% Polyplastron multivesiculatum. This composition was similar to the prevalence of these species in the rumen fluid of our fistulated sheep. Stock solutions were stored in PBS containing $1 \%$ formalin prior to use for vaccines.

The maximum cell concentrations we could obtain of the stock solutions for the vaccines were $T$. corlissi $1 \times 10^{6}$ cells $/ \mathrm{ml}$, Entodinium $3 \times 10^{7}$ cells $/ \mathrm{ml}$ and mixed rumen protozoa $3 \times 10^{6}$ cells $/ \mathrm{ml}$.

The vaccines were prepared from the protozoa cell stock solutions using previously described methods ${ }^{14}$. Briefly, a sterile solution of Saponin 'Quil A' was added to an equal volume of protozoa cell stock solution. Sterile PBS was added to make the total volume up to $40 \%$ of the final vaccine volume. The 'Quil A' and cells solution was then emulsified into a volume of filter sterilized Montanide Incomplete Seppic Adjuvant, equal to $60 \%$ of the final vaccine volume. Prior to in vivo use, vaccines were tested for mycoplasm contamination and bacterial and fungal contamination as per 9CFR (United States Department of Agriculture Code of Federal Regulations) 113.28 and 9CFR 113.27(d), respectively.

Prepared vaccine was stored at $4^{\circ} \mathrm{C}$ for less than $2 \mathrm{~d}$ before use. The vaccines $(2 \mathrm{ml}$ dose $)$ were aliquoted into syringes ( $3 \mathrm{ml}$ capacity with 18 -gauge needles) just prior to vaccination of individual sheep. Immunizations were administered into opposite sides of the neck. Local reactions at the site of vaccination were examined weekly for 6 weeks after vaccination occurred according to Australian Pesticides and Veterinary Medicine Authority requirements.

\section{Blood and saliva collections and analyses}

Blood $(10 \mathrm{ml})$ was collected and plasma taken from all sheep before feeding, as previously described ${ }^{14}, 8 \mathrm{~d}$ prior to primary vaccination and on days 13, 27, 41, 55, 70, 83 and 125. Mixed saliva $(10 \mathrm{ml})$ was collected and processed ${ }^{14}$ from all sheep 30 to $150 \mathrm{~min}$ after feeding $4 \mathrm{~d}$ prior to primary vaccination and on days 38 and 80 .

Specific anti-Tetrahymena corlissi, anti-Entodinium or antimixed rumen protozoa $\mathrm{IgG}$ antibody levels in the sheep plasma (samples collected up to day 83) and saliva were determined by ELISA analysis as described in Wright et $a l .{ }^{14}$, with several modifications. After the initial coating of plates with poly-L-lysine and the washes in PBS, plates were incubated overnight with protozoa cells (i.e. Tetrahymena, Entodinium or mixed rumen protozoa) rather than methanogen cells, with the amount of protein added per well the same for each cell type. The equivalent protein concentration for $10^{5}$ cells of each of the protozoa cell antigen groups was determined by the BioRad protein assay based on the Bradford ${ }^{15}$ method. The mixed rumen protozoa cells had approximately six times the protein concentration of that of Entodinium or $T$. corlissi cells $(0.29 v .0 .05$ and $0.04 \mathrm{mg} / \mathrm{ml}$ ). Thus, it was decided to use the mixed rumen protozoa cells' protein concentration so the antigen would be present in excess compared with the antibodies. For the mixed rumen protozoa, $10^{5}$ cells was equivalent to $4.3 \mu \mathrm{g}$ protein and it was resolved that $5 \mu \mathrm{g}$ total protein would be used per well for all the antigen groups. The protozoa cells were sonicated on ice at a power of 1000 watts for 5 min continuously (Microson XL Ultrasonic cell disruptor; Misonix Inc., New York, USA) prior to being incubated in the plate wells.

After washing plates in a PBS and $0.05 \%$ Tween 20 solution (PBST) and blocking with milk powder, either plasma, saliva or rumen fluid were added and the plates incubated. The starting dilution for the plasma was 1:50, which was then serially diluted from $1: 4$ to $1: 204800$. The starting dilution for the saliva and rumen fluid was $1: 4$, which was serially diluted to $1: 16384$. Plates were then washed in PBST and incubated with alkaline phosphatase-conjugated donkey anti-ovine IgG-IgG diluted in PBST containing $\mathrm{MgCl}_{2}$ and $\mathrm{ZnCl}_{2}$. After further washing in PBST containing $\mathrm{MgCl}_{2}$ and $\mathrm{ZnCl}_{2}$, plates were incubated with a phosphatase substrate and absorbance measured at $405 \mathrm{~nm}$. Antibody titre was determined at the half-maximum absorbance for each sample, done in triplicate on the same microtitre plates rather than on separate plates.

\section{Rumen fluid collection and analyses}

Rumen fluid (30 to $60 \mathrm{ml}$ ) was collected using a stomach tube and vacuum pump from all sheep, 150 to $190 \mathrm{~min}$ after feeding, $7 \mathrm{~d}$ prior to primary vaccination and on days 35 and 84 for protozoal cell counts. Rumen fluid $(1 \mathrm{ml})$ was immediately added to $15 \mathrm{ml} 1 \%$ formalin and samples stored at room temperature.

Protozoa in rumen fluid were counted by light microscopy with a Sedgewick-Rafter counting chamber of $1 \mathrm{ml}$ volume (Whitlock \& Co., Eastwood, NSW, Australia) as previously described $^{16}$

Rumen fluid was also collected from all sheep twice on day 118 (pre-feeding and 150 to $180 \mathrm{~min}$ post-feeding) by the afore-mentioned method. Rumen fluid $(5 \mathrm{ml})$ was then acidified $(1 \mathrm{ml} 0.1 \mathrm{M}-\mathrm{HCl})$, centrifuged $(3000 \mathrm{~g}$ for $15 \mathrm{~min})$ and the supernatant stored at $-40^{\circ} \mathrm{C}$. Ruminal fluid ammonia-N concentration was determined on a Technicon Autoanalyser II S.C. colorimeter (Technicon (Ireland) Ltd, Swords Co. Dublin, Republic of Ireland) using Technicon Industrial Method No. 334-74W/B ${ }^{+}$.

\section{Wool growth and live weight gain}

Wool growth during the pre-treatment covariate period and between days 81 and 123 was determined from mid-side patches ${ }^{17}$. LW was recorded at approximately 3-weekly intervals throughout the experiment. 
In vitro investigation of binding of IgG antibodies to protozoa cells

The in vitro investigations utilized various protozoa cells, which were extracted and prepared as described earlier. Antibodies were sourced from serum and saliva of sheep in the current experiment and also from sheep that had been vaccinated with $T$. corlissi cells, Entodinium spp. cells or vestibuliferid cells (Dasytricha ruminantium, Isotricha intestinalis and I. prostoma) previously and separately to the animals in the current experiment. Serum from sheep vaccinated with Entodinium spp. cells in this earlier work was freeze dried to increase the antibody concentration.

The indirect fluorescence antibody test ${ }^{5,18}$ was used to detect if the specific anti-protozoa IgG antibodies were binding to protozoa cells and if the binding could be quantified. To detect binding, cells $\left(10^{5}\right.$ in $100 \mu \mathrm{l}$ PBS $)$ were mixed with $200 \mu \mathrm{l}$ serum or saliva (1:10, 1:20 and 1:100 dilution) in PBS in $2 \mathrm{ml}$ eppendorf tubes and incubated at $39^{\circ} \mathrm{C}$ for $1 \mathrm{~h}$ at $100 \mathrm{rpm}$. The tubes were spun $(1010 \mathrm{~g}$ for $2 \mathrm{~min})$ and the supernatant removed. The pellet was washed three times in $0.5 \mathrm{ml}$ PBS, spun ( $1010 \mathrm{~g}$ for $2 \mathrm{~min}$ ) and centrifuged. The pellet was then re-suspended in $100 \mu$ l fluorescein isothiocyanate conjugated donkey anti-sheep IgG (diluted 1:40 in PBS) (Sigma F7634; Sigma-Aldrich, St Louis, MO, USA). The tubes were incubated, spun and washed as detailed earlier and the pellet re-suspended in $100 \mu \mathrm{l} \mathrm{PBS}$. The final preparations (each treatment in triplicate) were examined microscopically and photographed using an Aristoplan microscope (Leitz Wetzlar, Germany) under epi-fluorescence with a K3 filter block (excitation and emission wavelength of 470-495 and $515 \mathrm{~nm}$, respectively) with computer imaging. The relative fluorescence intensity (relative fluorescence units; RFU) was measured $(100 \mu \mathrm{l})$ on a Polar Star optima plate reader (BMG Labtechnologies, Germany) using filter 3 (excitation and emission wavelength of 485 and $520 \mathrm{~nm}$, respectively).

To quantify the binding, the volume and concentration of specific $\operatorname{IgG}$ anti-protozoa antibodies needed to bind 1500 cells of T. corlissi, Entodinium spp. or mixed rumen protozoa was determined. Each well of microtitre plates was coated with 1500 whole cells of either T. corlissi, Entodinium spp. or mixed rumen protozoa. Pre- and post-vaccination serum was diluted and added to the wells $(60 \mu \mathrm{l})$ of the microtitre plates to correspond to the cells they had been raised against (e.g. anti-T. corlissi serum was added to wells that had been coated with $T$. corlissi cells). Each dilution was done in triplicate or quadruplicate. Fluorescein isothiocyanate $(75 \mu \mathrm{l})$ was added and plate washes were performed three times in PBST. RFU were measured on the plate reader.

To determine if the antibody-antigen complexes caused the death of protozoa cells, serum and/or saliva containing specific antibodies was incubated with rumen fluid. Four experiments were carried out, each involving the same three treatments: (1) $5 \mathrm{ml}$ rumen contents and $0.5 \mathrm{ml} \mathrm{PBS}$; (2) $5 \mathrm{ml}$ rumen contents and $0.5 \mathrm{ml}$ pre-vaccination serum; (3) $5 \mathrm{ml}$ rumen contents and $0.5 \mathrm{ml}$ post vaccination serum. However, the type of anti-protozoa $\operatorname{IgG}$ antibody (anti- $T$. corlissi, anti-Entodinium spp, anti-mixed rumen protozoa or anti-vestibuliferida) in the serum differed in each experiment. The number of replicates of each treatment also varied between experiments.
For Expt 1, serums containing anti-T. corlissi IgG antibody were pooled from five sheep and had pre- and post-vaccination titres of $0 \mathrm{U}$ and $188987 \mathrm{U}$, respectively. There were eight replicates of each treatment. For Expt 2, serum from two sheep vaccinated with Entodinium spp. was pooled and concentrated by freeze drying. The pre- and post-vaccination anti-Entodinium IgG antibody titres for the freeze-dried preparations were $87 \mathrm{U}$ and $3377 \mathrm{U}$ respectively. The three treatments were done in triplicate. In Expt 3, serums containing anti-mixed rumen protozoa IgG antibody were pooled from six sheep and had pre- and post-vaccination titres of $0 \mathrm{U}$ and $26162 \mathrm{U}$, respectively. There were eight replicates of each treatment here. For Expt 4, serums containing antivestibuliferida IgG antibody had pre- and post-vaccination titres of $0 \mathrm{U}$ and $4758 \mathrm{U}$, respectively. Treatments were tested in duplicate in the latter experiment.

For all experiments, rumen contents were collected $3 \mathrm{~h}$ after feeding from the two fistulated wethers described earlier. Contents $(250 \mathrm{ml}$ per animal) were collected by suction via a vacuum pump through a brass filter $(30 \mathrm{~mm} \times 1.5-2.0 \mathrm{~mm}$ pore size) directly into a $500 \mathrm{ml}$ thermos flask. When the flask was filled, the contents were immediately put under $100 \% \mathrm{CO}_{2}$. Contents were then strained through four layers of cheesecloth into a $500 \mathrm{ml} \mathrm{Schott} \mathrm{bottle.} \mathrm{The} \mathrm{strained}$ rumen fluid was then transferred to a shaking water bath at $39^{\circ} \mathrm{C}$. In $100 \% \mathrm{CO}_{2}$, the rumen fluid was transferred in $5 \mathrm{ml}$ aliquots to $18 \times 150 \mathrm{~mm}$ anaerobic culture tubes, capped with butyl rubber stoppers, sealed with aluminium caps and crimped. The tubes were kept at $39^{\circ} \mathrm{C}$ in the water bath for $<1 \mathrm{~h}$ until treatments $(0.5 \mathrm{ml})$ were added via $1 \mathrm{ml}$ sterile syringes that had been flushed with $100 \% \mathrm{CO}_{2}$. The treatments (i.e. PBS and serums) were also transferred to $50 \mathrm{ml}$ serum bottles, flushed with $100 \% \mathrm{CO}_{2}$ and kept at $39^{\circ} \mathrm{C}$ prior to addition to the tubes.

Once the treatments were added to the rumen fluid, the tubes were gently inverted to mix and the tubes incubated for $4 \mathrm{~h}$. Samples $(0.1 \mathrm{ml})$ were taken at $0 \mathrm{~h}$, immediately after treatment addition and at $4 \mathrm{~h}$ and protozoal cell numbers were determined by microscopy. Expt 4 was undertaken for $8 \mathrm{~h}$ instead of $4 \mathrm{~h}$ and anti-vestibuliferida $\mathrm{IgG}$ antibody titre levels were also monitored throughout this experiment using ELISA analysis.

\section{Statistical analyses}

Data measured over time (plasma titres, rumen protozoa numbers and site reaction volumes) were analysed by repeated measures restricted maximum likelihood (REML) using a uniform correlation model. Vaccine treatment and time were fitted in the model as fixed effects and times for each animal were fitted as random effects. For plasma titres, data were log-transformed before analysis and each protozoa vaccine formulation was tested separately against the negative control using the same model. Protozoa cell count data were log-transformed and site reaction volume data were square root-transformed before analyses. Simple linear regression analysis was used on log-transformed titre values, across the three vaccine formulations, to determine the relationship between saliva IgG titres and plasma IgG titres.

The effects of vaccine formulation on feed intake, rumen parameters, LW gain and wool production were analysed 
according to a completely randomized design by one-way ANOVA (Genstat 8; Lawes Agricultural Trust, Rothamstead, UK). When a significant F-value was detected, means were compared by the least significant difference test. Treatment means for wool growth were covariance adjusted.

In in vitro Expt 1, 2 and 3, the effects of treatments on cell counts were analysed according to a split plot design using ANOVA. Statistical analysis was not done for Expt 4 as the treatments were only done in duplicate.

\section{Results}

Titres

Titres of $\operatorname{IgG}$, specific for the antigens that were in the various vaccine formulations, were detected in plasma and saliva of the sheep receiving the respective vaccines (Fig. 1). Titres in plasma were 300 - to 1500 -fold greater than those recorded in saliva, depending on the vaccine formulation. Secondary vaccination increased $(P<0.05)$ specific titres 5-fold in sheep receiving positive control and 3 -fold in sheep receiving Entodinium or mixed rumen protozoa. Specific titres in sheep receiving positive control were much higher than titres in sheep receiving vaccines formulated from rumen protozoa. Specific IgG titres were not detectable in sheep receiving the negative control vaccine.

There was a positive linear relationship $(P<0 \cdot 001)$ between plasma specific IgG titres and saliva specific IgG titres in sheep 6 weeks after secondary vaccination. The equation was:

$\log ($ saliva IgG titre +1$)=1.438 * \log ($ Plasma IgG titre +1$)$

$-4.979\left(100 R^{2}\right.$ 55.6; residual.s.d. 0.537, CV 0.38, n 60).

\section{Rumen protozoal numbers}

There was large variation between sheep in the numbers of protozoa in the rumen (Fig. 2). There was no effect $(P=0.741)$ of vaccination on rumen total protozoal numbers 6 weeks after primary or secondary vaccinations. Total protozoal numbers in the rumen were higher $(P<0.001) 6$ weeks after secondary vaccination than prior to vaccination or 6 weeks after primary vaccination.

\section{Blood and rumen metabolites}

There was no effect $(P>0.05)$ of vaccination on the rumen fluid $\mathrm{pH}$ or ammonia- $\mathrm{N}$ concentrations, which averaged 7.03 and $46.8 \mathrm{mg} / \mathrm{l}$ before feeding and 5.53 and $72.3 \mathrm{mg} / \mathrm{l}$ after feeding. Concentration of urea- $\mathrm{N}$ in the plasma of sheep 12 weeks post-secondary vaccination with positive control $(172 \mathrm{mg} / \mathrm{l})$ was higher $(P=0 \cdot 049)$ than in sheep vaccinated with negative control $(148 \mathrm{mg} / \mathrm{l})$ or Entodinium $(153 \mathrm{mg} / \mathrm{l})$. Sheep vaccinated with mixed rumen protozoa had an intermediate concentration $(160 \mathrm{mg} / \mathrm{l})$.

\section{Feed intake and animal production}

Vaccination had no effect $(P>0.05)$ on daily feed intake, which increased from 831 to $953 \mathrm{~g}$ over the experimental period. LW gain averaged $74 \mathrm{~g} / \mathrm{d}$ over the experiment and was not affected
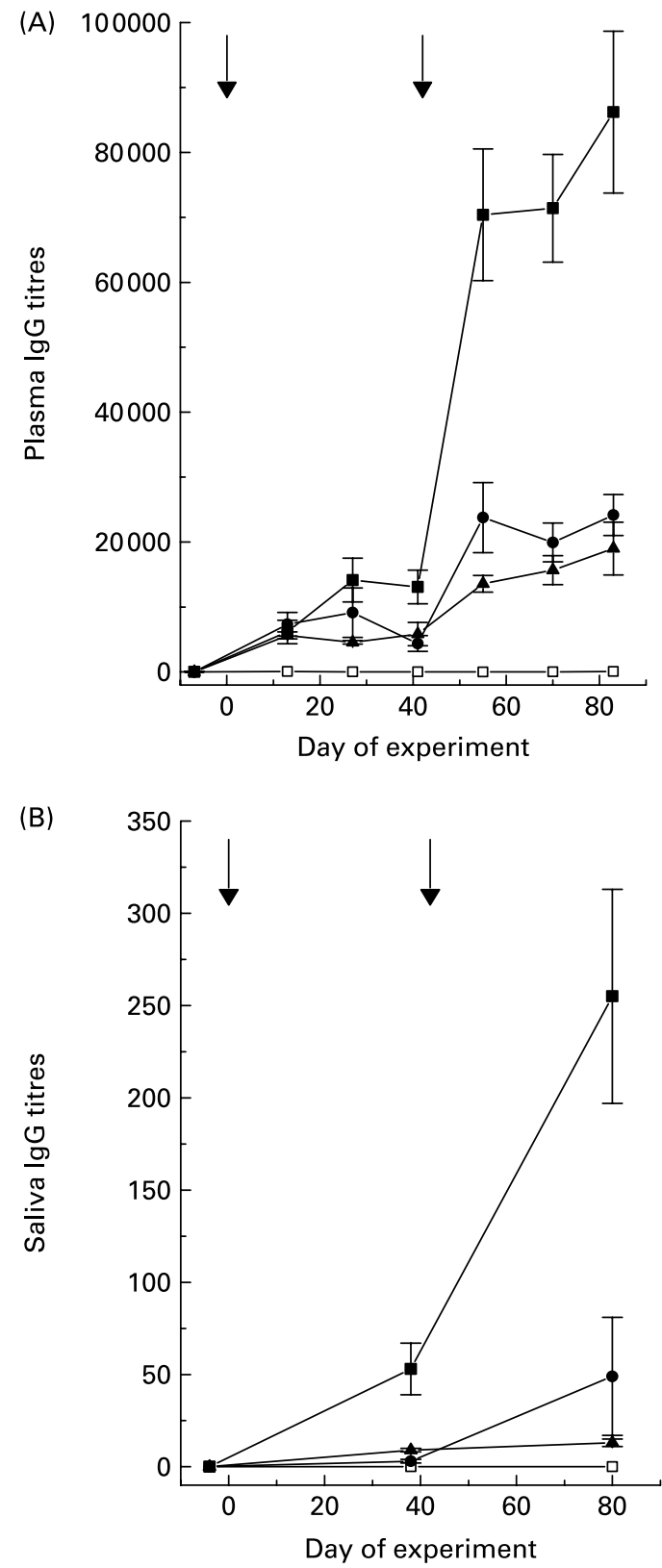

Fig. 1. Plasma (A) and saliva (B) specific IgG titres of sheep after primary vaccination at day 0 and secondary vaccination at day 42 with control $(\square)$, Tetrahymena corlissi $(\boldsymbol{\square})$, Entodinium $(\mathbf{\Lambda})$ or mixed rumen protozoa $(\bullet)$ vaccine formulations. $\downarrow$ Indicates times of vaccinations. For details of animals and procedures, see Experimental methods.

$(P>0.05)$ by vaccination. Clean wool growth of the sheep during the production measurement period averaged $89 \mathrm{mg} /$ $100 \mathrm{~cm}^{2}$ per $\mathrm{d}$ and was also not affected $(P>0.05)$ by vaccination.

\section{In vitro binding experiments}

Specific IgG anti-protozoa antibodies, generated by vaccination of sheep, bound to the rumen protozoa cells they were raised against when incubated in vitro with those cells (Fig. 3). There was no cross-reactivity between the anti-T. corlissi IgG antibodies and vestibuliferid cells or the anti-vestibuliferid antibodies and T. corlissi cells (Fig. 4). Cross reactivity 


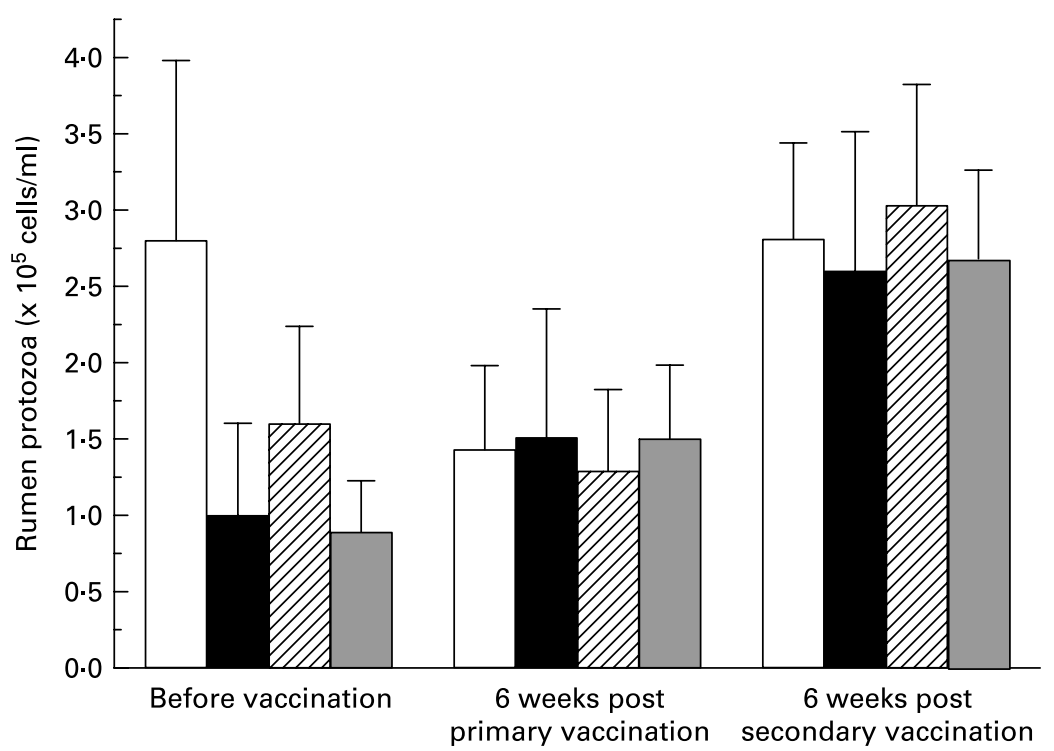

Fig. 2. Numbers of rumen ciliated protozoa in the rumen of sheep before and after vaccination with negative control ( $\square$ ), positive control ( $\square$ ), Entodinium (ש्/C) or mixed rumen protozoa $(\square)$ vaccine formulations. Values are means with their standard errors. For details of animals and procedures, see Experimental methods.

between anti-T. corlissi IgG antibodies and Entodinium spp. cells or the anti-Entodinium IgG antibodies and T. corlissi cells was unable to be determined, despite repeated efforts.

When quantifying the binding of antibodies to cells, there was a significant difference $(P<0.001)$ in the RFU between pre- and post-vaccination serums at all dilutions tested on $T$. corlissi cells. There was no significant difference in the RFU between pre- and post vaccination serums when they were used at 1:3 dilution on mixed rumen protozoa cells or at 1:2 dilution on Entodinium spp. cells (Fig. 5), but at greater dilutions there was a difference $(P<0 \cdot 001)$ in RFU between the pre- and post-vaccination serums used on mixed rumen protozoa and Entodinium spp. cells. The serum dilutions that gave the highest significant measurements of RFU were 1:375 for $T$. corlissi cells, 1:50 for Entodinium spp. cells and 1:75 for mixed rumen protozoa. At these dilutions, the serums used on each cell type had specific IgG titre levels of 471, 493 and $447 \mathrm{U}$ respectively. Therefore, for all three protozoa groups $60 \mu \mathrm{l}$ serum with a specific $\operatorname{IgG}$ titre of approximately $500 \mathrm{U}$ was optimal for 1500 cells in each well.

The strained rumen fluid obtained from the fistulated sheep for the in vitro incubation studies only contained Entodinium spp. and vestibuliferid cells. The Entodinium spp. cells comprised $89.8-94.0 \%$ of the total protozoa number and the cells from the order vestibuliferida ranged from $6 \cdot 0-10 \cdot 2 \%$.

In Expt 1, addition of post-vaccination serum containing $T$. corlissi antibodies to rumen fluid resulted in a reduction in total protozoa cells $(P=0.032)$ present compared with the addition of PBS, but not compared with when pre-vaccination serum was added (Table 1). Treatment did not affect $(P=0.061)$ the number of Entodinium spp. cells present. Numbers of total protozoa cells and Entodinium spp. cells did not differ $(P>0.05)$ within a treatment between the two sampling times. There was an interaction $(P=0.003)$ between treatment and time in the effects on vestibuliferid cells. There was no effect $(P>0.05)$ of treatment on numbers of cells belonging to the order Vestibuliferida immediately after addition of the treatments, but $4 \mathrm{~h}$ after addition there were less $(P<0.05)$ vestibuliferid cells in the rumen fluid that received post-vaccination serum compared with rumen fluid that received PBS or pre-vaccination serum.

In Expt 2, total protozoa cell numbers and Entodinium spp. cell numbers were reduced $(P<0 \cdot 05)$ with the addition of pre-vaccination serum compared with PBS, and cell numbers were further reduced $(P<0.05)$ when post-vaccination serum containing Entodinium antibodies was added (Table 1). Addition of post-vaccination serum increased $(P=0.034)$ numbers of vestibuliferid cells compared with pre-vaccination serum. Numbers of total protozoa cells and Entodinium spp. in the rumen fluid were greater $(P<0.05) 4 \mathrm{~h}$ after addition of treatments compared with immediately after. Numbers of vestibuliferid cells did not differ $(P>0.05)$ between sampling times.

For Expt 3, numbers of all three cell type groups were reduced $(P<0.05)$ when post-vaccination serum containing mixed rumen protozoa IgG was added compared with PBS and pre-vaccination serum (Table 1). Numbers of total protozoa cells and Entodinium spp. cells were higher $(P<0.05) 4 \mathrm{~h}$ after addition of treatments compared with immediately after. Numbers of vestibuliferids, on the other hand, were greater $(P=0.018)$ immediately after addition of treatment than compared with $4 \mathrm{~h}$ later.

In Expt 4, there was a $13.7 \%$ decrease in total protozoa cell numbers when post-vaccination serum was added to the rumen fluid (Table 1). The anti-vestibuliferida antibody titre levels measured during the incubation in rumen fluid that received the post-vaccination serum were $255 \mathrm{U}$ directly after addition of serum to the rumen contents, $205 \mathrm{U}$ after $2 \mathrm{~h}, 196 \mathrm{U}$ after $4 \mathrm{~h}, 277 \mathrm{U}$ after $6 \mathrm{~h}$ and $128 \mathrm{U}$ at $8 \mathrm{~h}$.

\section{Discussion}

Contrary to the hypothesis, sheep immunized with a vaccine containing fixed, rumen protozoal cells as antigens did not show a decrease in rumen protozoal numbers. The lack of 

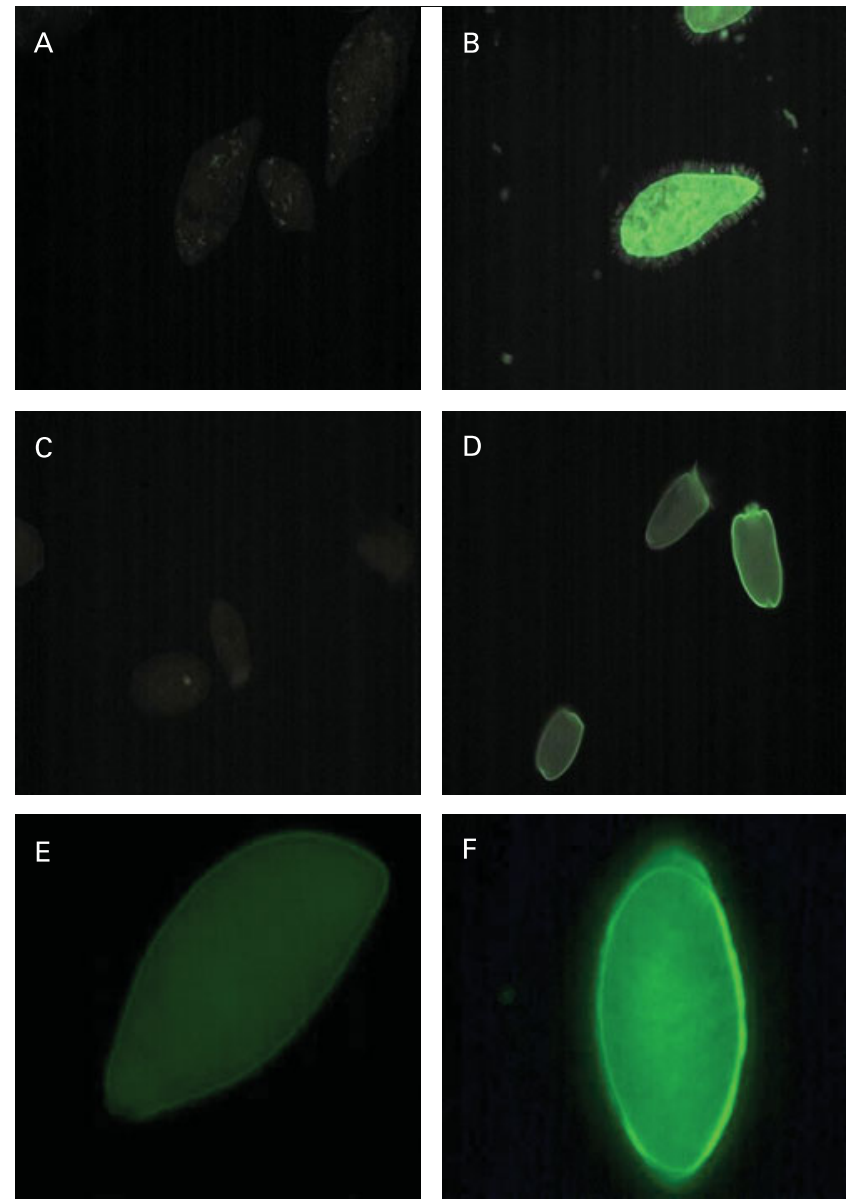

Fig. 3. The binding of antibodies in sheep saliva to Tetrahymena corlissi cells $(A, B ; \times 320$; length $50-70 \mu \mathrm{m})$, Entodinium cells $(C, D ; \times 320$; length 28-70 $\mu \mathrm{m})$ and Isotricha prostoma $(\mathrm{E}, \mathrm{F} ; \times 320$; length: $80-200 \mu \mathrm{m})$ (order Vestibuliferida). Saliva used on each protozoa cell type was collected from animals vaccinated with formulations containing the cell type of interest. Images on the left used saliva collected prior to vaccination and images on the right used saliva collected after sheep were vaccinated. The brightness of the cells indicates the IgG antibodies in the saliva binding to the surface antigens protozoa cells. For details of animals and procedures, see Experimental methods.

change in rumen ammonia concentration and wool growth was consistent with this result.

Vaccination did elicit a humoral immune response as indicated by the plasma and saliva specific IgG titres observed in the sheep, and specific anti-protozoal IgG was also delivered to the rumen as indicated by the titres in the rumen fluid. In vitro studies also showed that the specific anti-protozoal IgG did bind to the cells it was raised against and, in the case of anti-Entodinium IgG, it was able to reduce Entodinium spp. cell numbers in rumen fluid immediately. Given that this was the case, and that Entodinium spp. make up such a large proportion of total protozoa cell numbers in the rumen, there are a number of possibilities that can be explored to explain the lack of positive response of the vaccine protocol used here to decrease numbers of rumen protozoa.

One possibility for the negative result observed here is that insufficient amounts of specific $\operatorname{IgG}$ were produced in the saliva and consequently delivered to the rumen to impact on the rumen protozoa. The rumen is not an immunologically

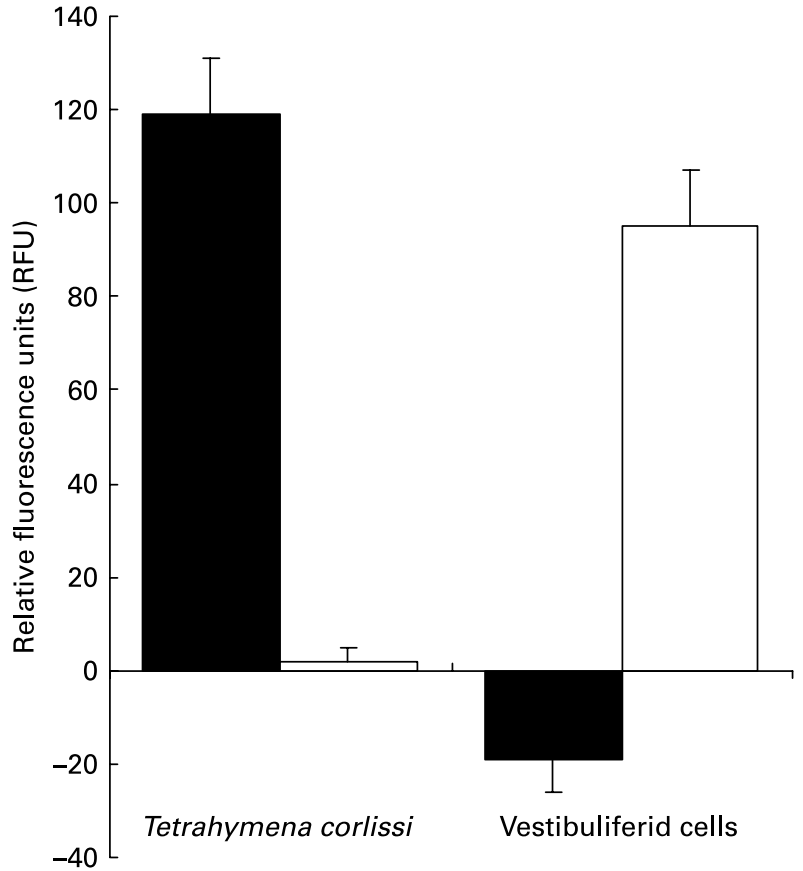

Fig. 4. Reactivity of Tetrahymena corlissi and vestibuliferid cells (Dasytricha ruminantium, Isotricha intestinalis and Isotricha prostoma) to serum containing IgG antibodies against $T$. corlissi ( $\square$ ) and mixed rumen protozoa ( $\square$ ). Fluorescence values have been corrected for background fluorescence that occurred when pre-vaccination serum was added to the cells. For details of animals and procedures, see Experimental methods.

active organ ${ }^{19,20}$. Antibodies binding to antigenic structures would not be expected to activate the complement cascade in the rumen, so this mechanism of action is unavailable in this anatomical location. Therefore, we are relying entirely on antibody being delivered to the rumen via the saliva. In ruminants, the majority of salivary IgG is transferred into saliva from serum ${ }^{19,21,22}$, but saliva only contains around $1-2 \%$ of the concentration of total $\mathrm{Ig}$ that are found in serum. IgG only comprises around $14 \%$ of the Ig in ruminant saliva $^{23,24}$. The predominant Ig in ruminant saliva is $\operatorname{IgA}$, which comprises $80-90 \%$ of the salivary Ig. The decision to focus on specific titres of IgG rather than IgA is due to previous studies showing that, after vaccination with rumen microbial antigens, specific IgG levels were higher in saliva and could be sustained compared with specific IgA levels ${ }^{14}$. The relationship between plasma and salivary IgG observed in the present experiment and in others ${ }^{14,25}$ suggests that specific IgG titres in saliva will increase if plasma titres are increased.

The amount of specific IgG required to be delivered to the rumen for the vaccine to be effective is unknown. The in vitro investigation undertaken here to quantify binding indicated that $60 \mu \mathrm{l}$ immune serum with a specific IgG titre of approximately $500 \mathrm{U}$ was optimal for binding 1500 cells of Entodinium spp. or mixed rumen protozoa on a microtitre plate. This equated to one unit of antibody binding fifty cells. It is unlikely that this binding relationship will be the same in a rumen, but it can provide an indication of what might be happening. If this relationship did hold, then we would need $16000000 \mathrm{U}$ antibody to bind to $2 \times 10^{5} \mathrm{cells} / \mathrm{ml}$ in a rumen containing 4 litres rumen fluid. With saliva titres of only 


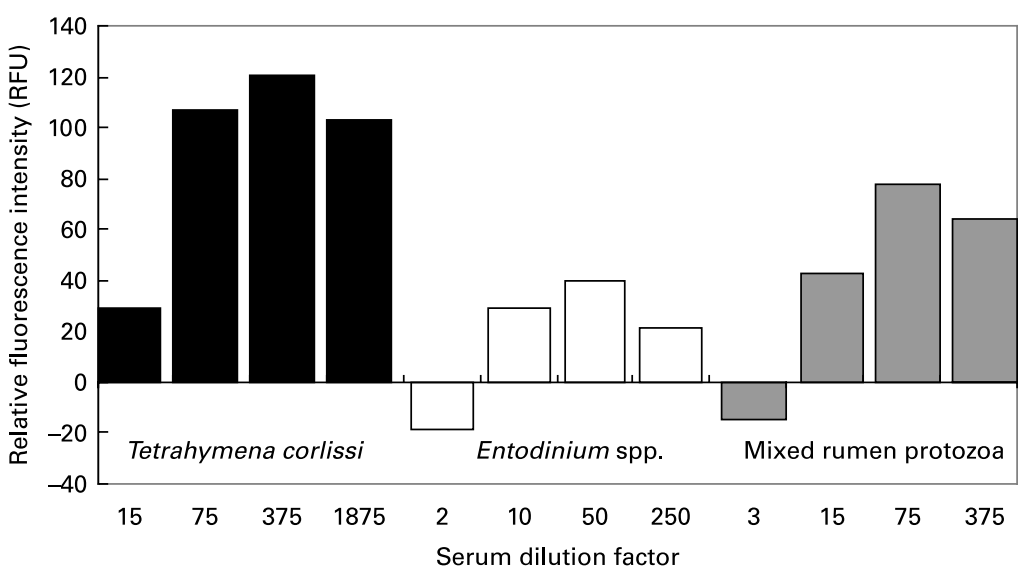

Fig. 5. Reactivity of 1500 cells of Tetrahymena corlissi $(\square)$, Entodinium spp. ( $\square$ ) or mixed rumen protozoa ( $\square$ ) with increasing dilutions of post-vaccination serum containing antibodies raised to the cells. Fluorescence values have been corrected for background fluorescence that occurred when pre-vaccination serum was added to the cells. For details of animals and procedures, see Experimental methods.

$50 \mathrm{U}$, we would need over 300 litres of saliva delivered to the rumen to provide enough antibodies for optimal binding (assuming a rumen volume of 4 litres with $2 \times 10^{5}$ cells $/ \mathrm{ml}$ ). Sheep are unlikely to produce more than 10 litres saliva per $\mathrm{d}^{26}$ so the current vaccine formulations need to be enhanced to produce greater immune responses.

Another aspect that is unknown is the quantitative relationship between binding and cell death. It is not known if optimal cell death rates occur at concentrations of antibody that were considered optimal for binding. The in vitro experiments can provide some indication of cell death rates in relation to antibody concentrations. When serum containing mixed rumen protozoa IgG antibodies was used, one unit of antibody resulted in a decrease of thirteen cells $(0.5 \mu l$ serum with a titre of $26162 \mathrm{U}$ reduced cell numbers by 30000 cells $/ \mathrm{ml}$ in a $5.5 \mathrm{ml}$ volume), which was approximately $25 \%$ of the optimal binding rate on the microtitre plate. This perhaps indicates that optimal binding rates on a titre plate do not translate well to kill rates in rumen fluid. An in vivo experiment where antibodies are delivered directly to the rumen contents in large amounts by external means, rather than in the small amounts that are currently possible by natural saliva inflow, may provide some indications of the antibody units needed in the rumen to be effective at reducing protozoa numbers.

Previous vaccination protocols aimed at generating antibodies against rumen-dwelling micro-organisms have reported successful results ${ }^{14,27-29}$. However, Gill et al. ${ }^{27}$ suggested that the selection of an optimal adjuvant was important in generating a

Table 1. Counts $\left(\times 10^{5}\right.$ cells $)$ of total protozoa cells, Entodinium spp. cells or cells belonging to the order Vestibuliferida from four rumen fluid in vitro experiments. Cells were counted immediately after $(0 \mathrm{~h})$ or $4 \mathrm{~h}$ after addition of PBS, serum collected from sheep before vaccination (PRE) or serum collected post-vaccination (POST) $\ddagger$

\begin{tabular}{|c|c|c|c|c|c|c|c|}
\hline \multirow[b]{2}{*}{ Experiment, antibody and cell type } & \multicolumn{3}{|c|}{ Treatment } & \multicolumn{4}{|c|}{ Time } \\
\hline & Control (PBS) & PRE serum & POST serum $†$ & SED & $\mathrm{Oh}$ & $4 \mathrm{~h}$ & SED \\
\hline \multicolumn{8}{|c|}{ Expt 1 - Tetrahymena corlissi IgG antibodies } \\
\hline Total protozoa & $4 \cdot 67^{\mathrm{b}}$ & $4 \cdot 60^{\mathrm{ab}}$ & $4 \cdot 38^{\mathrm{a}}$ & 0.106 & 4.53 & 4.58 & 0.661 \\
\hline $\begin{array}{l}\text { Entodinium spp. } \\
\text { Vestibuliferida }\end{array}$ & $4 \cdot 34^{\mathrm{b}}$ & $4 \cdot 19^{\mathrm{ab}}$ & $4 \cdot 07^{\mathrm{a}}$ & 0.105 & $4 \cdot 16$ & $4 \cdot 24$ & 0.699 \\
\hline \multicolumn{8}{|l|}{ Vestibuliferida } \\
\hline $\begin{array}{l}0 \mathrm{~h} \\
4 \mathrm{~h}\end{array}$ & $\begin{array}{l}0.33^{\mathrm{o}} \\
0.36^{\mathrm{b}}\end{array}$ & $\begin{array}{l}0.36^{\circ} \\
0.34^{b}\end{array}$ & $\begin{array}{l}0.34^{\circ} \\
0.23^{\mathrm{a}}\end{array}$ & 0.025 & & & \\
\hline \multicolumn{8}{|l|}{ Expt 2 - Entodinium IgG antibodies } \\
\hline Total protozoa & $3.05^{\mathrm{c}}$ & $2 \cdot 83^{\mathrm{b}}$ & $2 \cdot 37^{\mathrm{a}}$ & 0.064 & $2 \cdot 65^{\mathrm{a}}$ & $2.85^{\mathrm{b}}$ & 0.059 \\
\hline Entodinium spp. & $2 \cdot 73^{\mathrm{c}}$ & $2 \cdot 52^{\mathrm{b}}$ & $1.98^{\mathrm{a}}$ & 0.057 & $2 \cdot 33^{\mathrm{a}}$ & $2 \cdot 49^{\mathrm{b}}$ & 0.048 \\
\hline Vestibuliferida & $0.31^{\mathrm{ab}}$ & $0.30^{\mathrm{a}}$ & $0.38^{\mathrm{b}}$ & 0.026 & 0.31 & 0.35 & 0.016 \\
\hline \multicolumn{8}{|c|}{ Expt 3 - mixed rumen protozoa IgG antibodies } \\
\hline Total protozoa & $1.69^{\mathrm{b}}$ & $1.70^{\mathrm{b}}$ & $1.37^{\mathrm{a}}$ & 0.616 & $1.48^{\mathrm{a}}$ & $1.69^{\mathrm{b}}$ & 0.479 \\
\hline Entodinium spp. & $1.62^{\mathrm{b}}$ & $1.62^{\mathrm{b}}$ & $1.34^{\mathrm{a}}$ & 0.611 & $1.43^{\mathrm{a}}$ & $1.64^{\mathrm{b}}$ & 0.475 \\
\hline Vestibuliferida & $0.07^{\mathrm{b}}$ & $0.07^{\mathrm{b}}$ & $0.03^{\mathrm{a}}$ & 0.003 & $0.06^{\mathrm{b}}$ & $0.05^{\mathrm{a}}$ & 0.002 \\
\hline \multicolumn{8}{|l|}{ Expt 4 - vestibuliferid IgG antibodies } \\
\hline Total protozoa* & 4.98 & 4.46 & 3.85 & & & & \\
\hline
\end{tabular}

a,b,c Mean values within a column with unlike superscript letters were significantly different (minimum $P<0.05$ ). ${ }^{*}$ Cells only counted $8 \mathrm{~h}$ after addition of treatments.

$\dagger$ The protozoal antibodies in the POST serum differed in each experiment.

$\ddagger$ For details of animals and procedures, see Experimental methods. 
maximal antibody response. It could be that selection of an adjuvant that optimizes the production of salivary antibodies is required for efficient anti-protozoal vaccination. Along with the choice of adjuvant, it is also likely that a more targeted approach such as the isolation of specific proteins (e.g. Profilin) to use as antigens would increase immune responses compared with a crude mixture of antigens, as found in a whole cell preparation, due to competition between proteins ${ }^{30}$.

Although rumen fluid is renowned for being highly proteolytic $^{31}$, the presence of free $\operatorname{IgG}$ antibody, as measured by titres, in the rumen fluid for up to $8 \mathrm{~h}$ in in vitro Expt 4 showed that the antibodies survived and maintained binding function for at least $8 \mathrm{~h}$ (Table 1). The decrease in titre level between 6 and $8 \mathrm{~h}$ may indicate that the IgG antibodies had started to degrade. The immediate decrease in titre level when antibodies were first added to the rumen fluid (44\% decrease after dilution is taken account of) indicates that antibody-antigen complexes formed rapidly in the in vitro experiments (Table 1). The present results support the findings of Gnansampanthan ${ }^{5}$, who tested the resistance of Ig to proteolysis in rumen fluid in vitro and reported that very little cleavage of purified IgG molecules or their individual polypeptide chains was evident up to the first $4 \mathrm{~h}$ of incubation.

The lack of cross-reactivity between anti-T. corlissi IgG antibodies and vestibuliferid cells as determined by indirect fluorescence antibody test methods indicated that $T$. corlissi would be a good choice as a positive control vaccination. Therefore, we were surprised when serum containing anti- $T$. corlissi antibodies caused the death of Entodinium spp. and vestibuliferid cells in rumen contents in vitro, particularly that it is phylogenetically distantly related to the rumen proto$\mathrm{zoa}^{32}$. It is possible that the indirect fluorescence antibody test methods were not sensitive enough to detect cross-reactivity and that cross-reactivity determinations are better served by ELISA assays ${ }^{33}$. Cell death was still at least half that of the Entodinium and mixed rumen protozoa preparations (Table 1) even though the specific titre of the serum containing anti-T. corlissi IgG antibodies were seven to fifty-six times greater than that of the specific titres of the serums containing rumen protozoa antibodies. In other words, the comparative flooding of the system may have led to a higher degree of indiscriminate binding. However, even though the positive control produced saliva titres five times higher than the rumen protozoa vaccines, this may not have been enough to reduce protozoa cell numbers if its effectiveness against rumen protozoa was low. So for our purposes, T. corlissi may have served well as a positive control under these conditions.

In closing, we have described a vaccination protocol that induces a serum antibody response against rumen protozoa in sheep, but fails to affect the numbers of protozoa in the rumen. In vitro studies showed that the antibodies do bind to and reduce protozoa numbers, but the amount of antibody generated by vaccination is not enough to produce results in an in vivo system. It is suggested that the vaccine could be improved if antigens of protozoa that need to be targeted to reduce their activity or cause cell death are determined and greater immune responses generated. The current study also highlights the need for improved understanding of the actions of rumen protozoa antibodies in rumen fluid and the relationships between levels of antibodies and numbers of ciliated protozoa in the rumen.

\section{Acknowledgements}

Funding for this project was provided by Australian wool producers and the Australian Government through Australian Wool Innovation Limited. We also acknowledge the technical support and expertise provided by Louis Klein, Claire Auckland, Qingmin Li, Roslyn Owen and Mike Carthew. Statistical advice was provided by Kevin Murray from the University of Western Australia Statistical Consulting Group.

\section{References}

1. Williams AG \& Coleman GS (1992) Effect of ciliate protozoa on the productivity of the host ruminant. In The Rumen Protozoa, pp. 165-172 New York: Springer-Verlag.

2. Bird SH (1991) The influence of the presence of protozoa on ruminant production: a review. In Recent Advances in Animal Nutrition in Australia, pp. 15-27 [DJ Farrel, editor]. Armidale, NSW, Australia: University of New England.

3. Jouany JP (1996) Effect of rumen protozoa on nitrogen utilization by ruminants. $J$ Nutr 126, $1335 \mathrm{~S}-1346 \mathrm{~S}$.

4. Jouany JP, Demeyer DI \& Grain J (1988) Effect of defaunating the rumen. Anim Feed Sci Tech 21, 229-265.

5. Gnanasampanthan G (1993) Immune responses of sheep to rumen ciliates and the survival and activity of antibodies in the rumen fluid, $\mathrm{PhD}$ thesis, University of Adelaide, Australia.

6. Gnanasampanthan G, Hynd PI \& Mayrhofer G (1994) Effect of sheep antibodies on engulfment of bacteria by rumen protozoa. Proc Aust Soc Anim Prod 20, 389.

7. NHMRC (2004) Australian Code of Practice for the Care and Use of Animals for Scientific Purposes, 7th edition, Canberra, Australia: Australian Government.

8. Baird DB (1994) The design of experiments with covariates, $\mathrm{PhD}$ thesis, University of Otago, New Zealand.

9. White CL, Masters DG, Peter DW, Purser DB, Roe SP \& Barnes MJ (1992) A multi element supplement for grazing sheep. I. Intake, mineral status and production responses. Aust J Agr Res 43, 795-808.

10. AFRC (1993) Energy and Protein Requirements of Ruminants. An advisory manual prepared by the AFRC Technical Committee on Responses to Nutrients. Wallingford, UK: CAB International.

11. ANKOM (2003) Method for Determining Neutral Detergent Fiber (aNDF) 05/03. Macedon, NY: ANKOM Technology.

12. Lynn DH, Gransden SG, Wright A-DG \& Josephson G (2000) Characterisation of a new species of the ciliate Tetrahymena (Ciliophora: Oligohymenophorea) isolated from the urineof a dog: first report of Tetrahymena from a mammal. Acta Protozool 39, 289-294.

13. Oxford AE (1958) Bloat in cattle IX. Some observations on the culture of the cattle rumen ciliate Epidinium ecaudatum Crawley occurring in quantity in cows fed on red clover (Trifolium pratense L.). NZ J Agr Res 1, 809-824.

14. Wright A-DG, Kennedy P, O’Neill CJ, Toovey AF, Popovski S, Rea SM, Pimm CL \& Klein L (2004) Reducing methane emissions in sheep by immunization against rumen methanogens. Vaccine 22, 3976-3985.

15. Bradford MM (1976) A rapid sensitive method for the quantization of microgram quantities of protein utilizing the principle of protein-dye binding. Anal Biochem 72, 248-254.

16. Skillman LC, Toovey AF, Williams AJ \& Wright A-DG (2006) Development and validation of a real-time PCR method to 
quantify rumen protozoa and examination of variability between Entodinium populations in sheep offered a hay-based diet. Appl Environ Microbiol 72, 200-206.

17. Schlink AC, Mata G, Lea JM \& Ritchie AJM (1999) Seasonal variation in fibre diameter and length in wool of grazing Merino sheep with low or high staple strength. Aust J Exp Agr 39, 507-517.

18. Sato S, Ogimoto K \& Nakai Y (1990) Localization of the bacterial antigens in calves inoculated orally with ruminal Bacteroides succinogenes and Selenomonas ruminantium. Jap J Vet Sci 52, 711-717.

19. Mach JP \& Pahud JJ (1971) Secretory IgA, a major immunoglobulin in most bovine external secretions. J Immunol 106, 552-563.

20. Sharpe ME, Latham MJ \& Reiter B (1975) The immune response of the host animal to bacteria in the rumen and caecum. In Proceedings of the IV International Symposium on Ruminant Physiology. Digestion and Metabolism in the Ruminant, pp. 193-204 [IW McDonald and ACI Warner, editors]. Sydney, Australia: The University of New England Publishing Unit.

21. Curtain CC, Clark BL \& Dufty JH (1971) The origins of the immunoglobulins in the mucous secretions of cattle. Clin Exp Immunol 8, 335-344.

22. Watson DL (1987) Serological responses of sheep to live and killed Staphylococcus aureus vaccines. Vaccine 5, 275-278.

23. Butler JE (1981) A concept of humoral immunity among ruminants and an approach to its investigation. In The Ruminant Immune System, pp. 3-55 [JE Butler, editor]. New York: Plenum Press.

24. Lascelles AK, Beh KJ, Mukkur TK \& Watson DL (1986) Mucosal immune system. In The Ruminant Immune System in Heath and Disease, pp. 429-457 [WI Morrison, editor]. Cambridge, UK: Cambridge University Press.
25. Shu Q, Gill HS, Hennessy DW, Leng RA, Bird SH \& Rowe JB (1999) Immunisation against lactic acidosis in cattle. Res Vet Sci 67, 65-71.

26. Kay RNB (1960) The rate of flow and composition of various salivary secretions in sheep and calves. $J$ Physiol 150, 515-537.

27. Gill HS, Shu Q \& Leng RA (2000) Immunization with Streptococcus bovis protects against lactic acidosis in sheep. Vaccine 18, 2541-2548.

28. Shu Q, Bird SH, Gill HS, Duan E, Xu Y, Hillard MA \& Rowe JB (2001) Antibody response in sheep following immunization with Streptococcus bovis in different adjuvants. Vet Res Comm 25, 43-54.

29. Shu Q, Hillard MA, Bindon BM, Duan E, Xu Y, Bird SH, Rowe JB, Oddy VH \& Gill HS (2000) Effects of various adjuvants on efficacy of a vaccine against Streptococcus bovis and Lactobacillus spp. in cattle. Am J Vet Res 61, 839-843.

30. Willasden P (1994) Vaccination against ectoparasites. In Vaccines in Agriculture: Immunological Applications to Animal Health and Production, pp. 171-176 [PR Wood, P Willasden, JE Vercoe, RM Hoskinson and D Demeyer, editors]. Melbourne, Australia: CSIRO.

31. Wallace RJ \& Cotta MA (1988) Metabolism of nitrogen-containing compounds. In The Rumen Microbial Ecosystem, pp. 217-249 [PN Hobson, editor]. Oxford, UK: Elsevier Science Publishers.

32. Wright A-DG \& Lynn DH (1997) Maximum ages of ciliate lineages estimated using a small subunit rRNA molecular clock: Crown eukaryotes that date back to the Paleoproterozoic. Archiv für Protist 148, 329-341.

33. Madigan MT, Martinko JM \& Parker J (2000) Brock Biology of Microorganisms, 9th edition pp. 867-868, London: PrenticeHall International (U.K.) Ltd. 